Hsie, N. Shen, A. Weder, R.L. Cooper, R. Lipshutz, and A. Chakravarti. 1999. Patterns of single-nucleotide polymorphisms in candidate genes for blood-pressure homeostasis. Nat. Genet. 22:239-247.

7.Henikoff, S., E.A. Greene, S. Pietrokovski, P. Bork, T.K. Attwood, and L. Hood. 1997. Gene families: the taxonomy of protein paralogs and chimeras. Science 278:609-614.

8.Kruglyak, L. 1997. The use of a genetic map of biallelic markers in linkage studies. Nat. Genet. 17:21-24

9.Kwok, P.Y., C. Carlson, T.D. Yager, W. Ankener, and D.A. Nickerson. 1994. Comparative analysis of human DNA variations by fluorescence-based sequencing of PCR products. Genomics 23:138-144.

10.Li, H., N.B. Schwartz, and B.M. Vertel. 1993. cDNA cloning of chick cartilage chondroitin sulfate (aggrecan) core protein and identification of a stop codon in the aggrecan gene associated with the chondrodystrophy, nanomelia. J. Biol. Chem. 268:23504-23511.

11.Li, H., M. Domowicz, A. Hennig, and N.B. Schwartz. 1996. S103L reactive chondroitin sulfate proteoglycan (aggrecan) mRNA expressed in developing chick brain and cartilage is encoded by a single gene. Mol. Brain Res. 36:309-321.

12.Nickerson, D.A., S.L. Taylor, K.M. Weiss, A.G. Clark, R.G. Hutchinson, J. Stengard, V. Salomaa, E. Vartiainen, E. Boerwinkle, and C.F.Sing. 1998. DNA sequence diversity in a 9.7-kb region of the human lipoprotein lipase gene. Nat. Genet. 19:233-240.

13.Smith, E. 1998. A sequence tagged site in the chicken based on primers specific for the mouse transcription factor core-binding factor alpha 1 CBFA1. Anim. Genet. 29:236-243.

14.Smith, E., L. Shi, P. Drummond, L. Rodriguez, R. Hamilton, E. Powell, S. Nahashon, S. Ramlal, and J. Foster. 2000. Development and characterization of expressed sequence tags for the turkey (Meleagris gallopavo) genome and comparative sequence analysis with other birds. Anim. Genet. 31:62-67.

15.Wang, D.G., J.B. Fan, C.J. Siao, A. Berno, P. Young, R. Sapolsky, G. Ghandour, N. Perkins et al. 1998. Large-scale identification, mapping, and genotyping of single-nucleotide polymorphisms in the human genome. Science 280:1077-1082.

Comments by Eric Wong on the manuscript as well as on interpretation of the data are gratefully acknowledged. The NHGRI and USDA-SCD programs provided support for our work. Address correspondence to Dr. Edward J. Smith, 3130 Litton Reaves Hall, Virginia Tech, Blacksburg, VA 24061,USA.e-mail:esmith@vt.edu

Received 29 August 2000; accepted 2 January 2001.

Edward J. Smith, Gliceria E. Smith, and Li Shi

Virginia Tech

Blacksburg, VA, USA

\section{Small Bones from Dried Mammal Museum Specimens as a Reliable Source of DNA}

BioTechniques 30:732-736 (April 2001)

Although many museums now routinely archive animal tissue for molecular systematic studies, the vast majority of museum specimens predate the advent of molecular techniques and consist of dried skins, skeletons, and formalin-fixed, ethanol-preserved tissues. The difficulties of obtaining usable DNA from such specimens are well known $(1,3,4,6,8)$, yet such specimens form a potentially invaluable source of data, especially for populations of animals that are extinct or locally extirpated. Engstrom et al. (3) pointed to the fact that bone may be a better source of DNA, particularly to obtain long fragments of DNA. However, the amount of material suggested by the authors from voucher specimens for PCR may be on the range of gram-quantities. During our studies of mitochondrial variation of fruit bats of the genus Sturnira, we were unable to amplify cytochrome $b$ from standard phenol-chloroform extractions of museum specimens. Consequently, we refined extraction protocols using only milligram-quantities that have routinely yielded amplifiable DNA from up to 66year-old museum skins, bones, and formalin-fixed, ethanol-preserved tissues from bats of the genus Sturnira. Our techniques are novel improvements of existing DNeasy ${ }^{\circledR}$ Tissue Extraction protocols (Qiagen, Valencia, CA, USA), apply to very tiny bones, and could potentially be used with other mammals and small vertebrates. These modifications are $(i)$ repeated washing and rehydration of tissues; (ii) prolonged (up to $72 \mathrm{~h}$ ) digestion and repeated additions of proteinase $\mathrm{K}$; (iii) checking and adjusting the $\mathrm{pH}$ of the extracted DNA solution before adsorption on the Qiagen column; (iv) reducing the elution volume; and ( $v$ ) amplification of short overlapping segments utilizing internal primers.

Samples consisted of museum specimens of Sturnira, frugivorous bats averaging about $20 \mathrm{~g}$. Samples from dried specimens included bones (ribs $5-9 \mathrm{~mm}$ in length or $2-3 \mathrm{~mm}$ of the diaphysis of a wing bone) or $3 \times 2 \mathrm{~mm}$ of dry skin with hair. Formalin-fixed, ethanol-preserved tissue samples included $3 \times 2 \mathrm{~mm}$ pieces of liver or skin with muscle or 1-2 ribs. Liquid-preserved tissue was chopped into small (< $0.5 \mathrm{~mm}$ ) pieces; dry bone was crushed within a folded piece of a $10 \times 10 \mathrm{~cm}$ weighing paper (Fisher Scientific, Pittsburgh, PA, USA) with a pair of needlenose pliers. Chopped or crushed sam ples were placed in $1.5-\mathrm{mL}$ tubes and washed 3-5 times in $250 \mu \mathrm{L} \mathrm{PBS} \mathrm{(9)} \mathrm{for}$ $10 \mathrm{~min}$ at $55^{\circ} \mathrm{C}$ with occasional vortex mixing. The sample was spun briefly, 
Table 1. Comparison of Different Tissue Sources and Preservation Methods on Successful PCR Amplification from Museum Specimens of Bats

\begin{tabular}{|ccccc|}
\hline \multirow{3}{*}{ wet } & $\begin{array}{c}\text { Tissue } \\
\text { Source }\end{array}$ & $\boldsymbol{n}$ & $\begin{array}{c}\text { Successful PCR } \\
\text { Amplifications }\end{array}$ & $\begin{array}{c}\% \\
\text { Success }\end{array}$ \\
& liver & 14 & 6 & 43 \\
& bone & 4 & 4 & 100 \\
& skin & 15 & 11 & 73 \\
dry & wet subtotal & 33 & 21 & 63 \\
& bone & 13 & 12 & 92 \\
& skin & 11 & 7 & 63 \\
& dry subtotal & 24 & 19 & 79 \\
& overall total & 57 & 40 & 70 \\
"Wet" $=$ formalin-fixed tissue stored in $70 \%$ ethanol. &
\end{tabular}

and the wash solution was decanted. We assumed that the repeated washes rehydrate the tissues and might remove PCR inhibitors and residual fixatives.

Digestion and extraction was performed with the DNeasy tissue extrac- tion kit (Qiagen), with modifications. These modifications consisted of $(i)$ prolonged (up to $72 \mathrm{~h}$ ) digestion with proteinase $\mathrm{K}$; (ii) checking and adjusting the $\mathrm{pH}$ of the extracted DNA solution before adsorption on the Qiagen

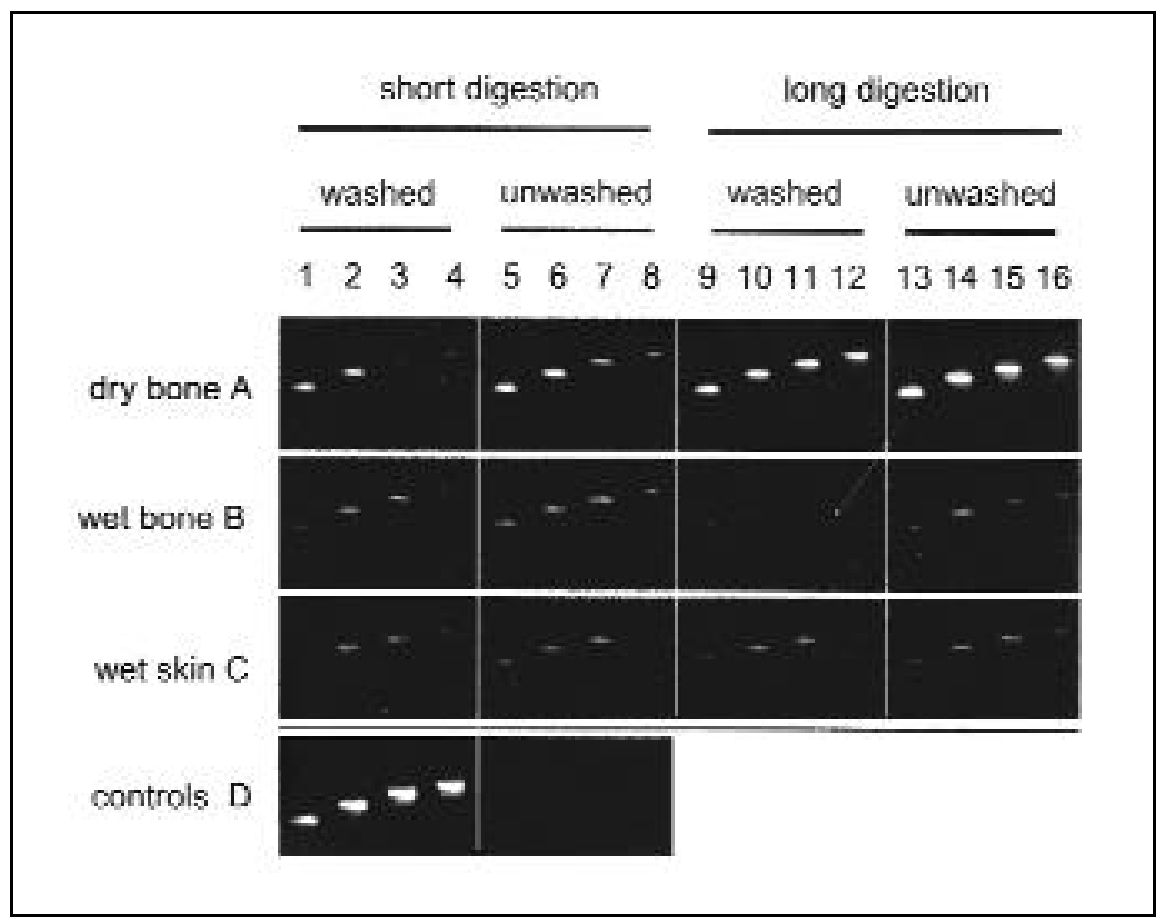

Figure 1. Ease of amplification of cytochrome $b$ from an 8-year-old bat museum specimen (wet material) and from a 19-year-old bat (dry material). Each sample was amplified using a forward primer (cyb 8) and one of four reverse primers, each yielding a product of successively greater length. Reverse primers and approximate length of product (when combined with forward primer cyb 8) are: 1R (279 bp); 2R (494 bp); 3R (698 bp); and cyb 7 (879 bp). Variables examined are tissue source, duration of rehydration (washed vs. unwashed), and duration of digestion ( $3 \mathrm{~h}$ vs. $72 \mathrm{~h}$ ). The best amplifications and longest PCR products were obtained from dry bones digested for $72 \mathrm{~h}$. Washing and rehydration before extraction appeared to have little or no effect. Amplifications from skin samples were inferior to those obtained from bone. Results from dry skin are not shown; results are similar to wet skin. Positive control template is bat DNA from saturated EDTA-DMSO saline (SED) buffer-preserved fresh kidney. column; and (iii) reducing the elution volume. To each tissue sample, $180 \mu \mathrm{L}$ buffer ATL (tissue lysis buffer; Qiagen) and $20 \mu \mathrm{L}$ proteinase $\mathrm{K}(20 \mathrm{mg} / \mathrm{mL}$; Qiagen) were added; the sample was incubated at $55^{\circ} \mathrm{C}$ with occasional vortex mixing or gentle shaking. Digestion continued for 24-72 h until the tissues were completely lysed. We considered the lysis of the sample complete when no more solid materials (including bone) were observable with the naked eye. During the digestion, fresh $20-\mu \mathrm{L}$ aliquots of proteinase $\mathrm{K}$ were added every $12 \mathrm{~h}$ until lysis was complete. When digestion was complete, $200 \mu \mathrm{L}$ buffer AL (lysis buffer; Qiagen) were added, the mixture was vortex mixed, and incubated at $70^{\circ} \mathrm{C}$ for $10 \mathrm{~min}$. Two hundred microliters of $100 \%$ ethanol were added, the sample was vortex mixed, and the $\mathrm{pH}$ was checked using color pHast ${ }^{\circledR}$ indicator strips (EM Science, Gibbstown, NJ, USA). The $\mathrm{pH}$ was adjusted to 7.0-6.5 with $0.25 \mathrm{M}$ $\mathrm{HCl}$; a pH greater than 7.0 will prevent adsorption of DNA onto the silica membrane of the Qiagen column. The pH-adjusted sample was passed through the Qiagen column; the column was washed with $500 \mu \mathrm{L}$ buffer AW1 (wash 1 buffer; Qiagen), $500 \mu \mathrm{L}$ buffer AW2 (wash 2 buffer; Qiagen), and then spun dry. DNA was eluted twice from the column in 40-50 $\mu \mathrm{L}$ buffer AE (elution buffer; Qiagen) (10 mM Tris, $\mathrm{pH}$ 8.0); column and buffer were incubated for $5 \mathrm{~min}$ at $65^{\circ} \mathrm{C}$ before centrifugation to increase the yield of DNA from the membrane. Aliquots of the resulting total DNA were usually too weak to be visualized on an agarose gel.

We sequenced a portion of cytochrome $b$ (approximately 850 bp total length) by amplifying four overlapping regions of approximately $250 \mathrm{bp}$ each. The outermost primers were those of Pääbo et al. (7) and Edwards et al. (2), called here Cytb8F and Cytb7R, respectively. Some highly degraded templates could not be amplified in one piece; consequently, internal primer pairs were designed from consensus sequences of Sturnira obtained from fresh tissue sam ples of six different species. Those primers were named bat1F $\left(5^{\prime}\right.$-AGCCACCGCATTCAACTCHG-3'), bat1R (5'-CCGTAGTTTACATCTCGGCAR$\left.3^{\prime}\right)$, bat2F (5'-TTCGCCGTCATAGCC- 
ACA-3'), bat2R (5'-TGGTGATGACTGTTGCTCCYC-3'), bat3F (5'-CCTMCTTCCCTTTATCGTAG-3' ${ }^{\prime}$ ), and bat3R $\quad\left(5^{\prime}\right.$-CYGGGTCTGATGGGATYCC $\left.-3^{\prime}\right)$. These primers produced four overlapping products (each approximately 200 bases) that covered almost the entire cytochrome $b$ region. Hot-start reactions $(50 \mu \mathrm{L})$ contained $5 \mu \mathrm{L} 10 \times$ PCR buffer (Sigma, St. Louis, MO, USA) (without $\mathrm{MgCl}_{2}, 100 \mathrm{mM}$ Tris$\mathrm{HCl}, \mathrm{pH} 8.3,500 \mathrm{mM} \mathrm{KCl}), 7 \mu \mathrm{L} 25$ $\mathrm{mM} \mathrm{MgCl}_{2}, 1 \mu \mathrm{L} 10 \mathrm{mM}$ dNTPs, $1 \mu \mathrm{L}$ each primer (10 pmol), $15 \mu \mathrm{L}$ of a saturated aqueous betaine solution, $15 \mu \mathrm{L}$ water, $5 \mu \mathrm{L}$ template, and $1 \mathrm{U}$ Taq DNA polymerase (Sigma). The thermocycler program consisted of an initial denaturation at $93^{\circ} \mathrm{C}$ for $3 \mathrm{~min}$, followed by 39 cycles of $94^{\circ} \mathrm{C}$ for $1 \mathrm{~min}, 52^{\circ} \mathrm{C}$ for $1 \mathrm{~min}$, $72^{\circ} \mathrm{C}$ for $1 \mathrm{~min}$, ending with a final elongation at $72^{\circ} \mathrm{C}$ for $3 \mathrm{~min}$. Products were visualized on a $1 \%$ agarose gel stained with ethidium bromide and cleaned using QIAquick ${ }^{\mathrm{TM}}$ columns (Qiagen). Products were cycle sequenced using BigDye $^{\mathrm{TM}}$ terminator mixture (Applied Biosystems, Foster City, CA, USA) according to the manufacturer's protocols. Both strands were sequenced to assure accuracy in base calling. Controls consisted of template-free reactions (negative) and high-quality Sturnira DNA from fresh tissues (positive).

The overlapping sequences were assembled and analyzed cladistically with other Sturnira sequences. All sequences obtained from old museum specimens (up to 66 years old) fell into expected clades and aligned well with sequences from DNA isolated from fresh tissue samples. There was no clear relationship between the age of the sample and the amplification success.

Consistently, all attempts of extractions on wet or old dry material with standard phenol-chloroform methodology (5) were unsuccessful. Our modified Qiagen extraction protocol yielded amplifiable DNA on $70 \%$ of the sam ples (Table 1). To investigate the relative quality of template DNA from various tissue sources, we tried primer pairs of increasing successive length on each template and compared the results (Figure 1). Contrary to our expectations, small rib bones from dried skeletons and liquid-preserved samples proved to be the best source of DNA.
Among dry samples, small ear pieces (with skin, hairs, and muscles), skin, and bones provided DNA with an overall yield of $63 \%$. Formalin-fixed, ethanol-preserved pieces produced DNA on $44 \%$ (liver) or $73 \%$ (skin) of the cases. As noted by Su et al. (10), "the success of DNA recovery depends largely on the original condition of the specimen". Many specimens "may not contain recoverable DNA due to overtreatment [or undertreatment] for antiseptic purposes or overdegradation [before or] in storage" (10).

In summary, old dried skins, skeletons, and formalin-fixed, ethanol-preserved mammal specimens represent a potentially valuable source of data. By applying these modifications (repeated washing and rehydration of tissues; repeated additions of proteinase $\mathrm{K}$ to facilitate complete digestion; amplification of short overlapping segments utilizing internal primers; and reduced elution volume), we obtained discrete amounts of amplifiable DNA from bats of the genus Sturnira. Although our study was limited to bats, we expect that these modified techniques should be applicable to the majority of vertebrate species. Our finding that small bones, only a few $\mathrm{mm}$ in length (less than $0.001 \mathrm{~g}$ ), are an excellent source of relatively undegraded DNA increases the value of museum specimens to systematic biologists.

\section{REFERENCES}

1.Chatigny, M.E. 2000. The extraction of DNA from formalin-fixed, ethanol-preserved reptile and amphibian tissues. Herpetol. Rev. 31:86-87.

2.Edwards, S.V., P. Arctander, and A.C. Wilson. 1991. Mitochondrial resolution of a deep branch in the genealogical tree for perching birds. Proc. R. Soc. London B 243:99-107.

3.Engstrom, M.D., R.W. Murphy, and O. Haddrath. 1999. Sampling vertebrate collections for molecular research: practice and policies, p. 315-330. In D.A. Metzger and S.C. Byers (Eds.), Managing the Modern Herbarium: An Interdisciplinary Approach. Society for the Preservation of Natural History Collections, Elton-Wolf Publishing, Vancouver, Canada.

4.Greenwood, A.D., C. Capelli, G. Possnert, and S. Pääbo. 1999. Nuclear DNA sequences from late Plaeistocene megafauna. Mol. Biol. Evol. 16:1466-1473

5.Hillis, D.M., B.K. Mable, A. Larson, S.K. Davis, and E.A. Zimmer. 1996. Nucleic acids IV: sequencing and cloning, p. 321-381.
In D.M. Hillis, C. Moritz, and B.K. Mable (Eds.), Molecular Systematics, 2nd ed. Sinauer Associates, Sunderland, MA.

6.McArthur, A.G. and B.F. Koop. 1999. Partial 28S rDNA sequences and the antiquity of hydrothermal vent endemic gastropods. Mol. Phylogenet. Evol. 13:255-274.

7.Pääbo, S., J.A. Gifford, and A.C. Wilson. 1988. Mitochondrial DNA sequences from a 7,000-year old brain. Nucleic Acids Res. 16:9775-9787.

8.Poinar, H.N., M. Hofreiter, W.G. Spaulding, P.S. Martin, B.A. Stankiewicz, H. Bland, R.P. Evershed, G. Possnert, and S. Pääbo. 1998. Molecular coproscopy: dung and diet of the extinct ground sloth Nothrotheriops shastensis. Science 281:402-406.

9.Sambrook, J., E.F. Fritsch, and T. Maniatis. 1989. Molecular Cloning: A Laboratory Manual. CSH Laboratory Press, Cold Spring Harbor, NY.

10.Su, B., Y.X. Wang, H. Lang, W. Wang, and Y.Zhang. 1999. Phylogenetic study of com plete cytochrome $b$ genes in musk deer (genus Moschus) using museum samples. Mol. Phylogenet. Evol. 12:241-249.

We are grateful to the many curators that trusted their specimens to us for DNA extraction. Sequencing was done at the DNA Sequencing Core at the University of Florida. We thank Ginger Clark for critically reading the manuscript. This publication represents Florida Museum of Natural History Contributions to Mammalogy Number 2. Address correspondence to Carlos Alberto Iudica, Mammalogy, Florida Museum of Natural History, Dickinson Hall, P.O. Box 117800, University of Florida, Gainesville, FL 32611-7800, USA. e-mail: casaiud@ flmnh.ufl.edu

Received 24 February 2000; accepted 27 November 2000.

\section{Carlos A. Iudica, W. Mark Whitten, and Norris $H$. Williams}
Florida Museum of
Natural History
Gainesville, FL, USA 